\title{
От терминологической ясности - к качеству научных дискуссий
}

(Рецензия на книгу: Отечественная теория медиа. Основные понятия. Словарь / под ред. Е.Л. Вартановой. М.: Фак. журн. МГУ; Изд-во Моск. ун-та, 2019)

Татьяна Фролова

@ Фролова Татьяна Ивановна доктор филологических наук, профессор кафедры периодической печати факультета журналистики МГУ имени М.В. Ломоносова (г. Москва, Россия), t_frolova@bk.ru
Вышел в свет словарь «Отечественная теория медиа. Основные понятия», созданный группой ученых факультета журналистики МГУ имени М.В. Ломоносова. Это ожидаемое и своевременное исследование. Потребность профессионального и научного сообществ в издании такого типа многократно высказывалась на различного рода дискуссионных площадках. Отечественную теорию медиа отличает очень невысокий уровень конвенциональности, параллельность процессов формирования понятий и дефиниций в теории и коммуникативных практиках, отсутствие общепризнанных унифицированных определений, нелегитимность многих из них, полемика вокруг даже устоявшихся понятий, отставание от стремительно расширяющегося поля медиареальности и множество других проблем, заметно осложняющих общение и согласие всех, кто причастен к медиасфере. «Терминологический беспорядок», по выражению одного из авторов словаря, существенно тормозит развитие теории медиа, нередко порождая в научных изданиях потоки излишнего информационного шума. В этих условиях словарь может рассматриваться как безусловный шаг вперед по пути решения названных проблем.

В реализации замысла, в числе основных достижений прежде всего хотелось бы выделить состав глоссария. Отобранных понятий, в сущности, немного, всего 100 , однако они дают ясное представление об авторской концепции отечественной теории медиа. Это современная и глубокая 
концепция, аккумулирующая достижения российских и зарубежных ученых последних десятилетий. Медиареальность, как известно, пережила за эти годы глобальную трансформацию. Отечественные медиа - как в теории, так и в практике - помимо общемировых процессов затронуло и радикальное изменение политико-экономических парадигм, распространившееся на самые основы медиапроизводста. Отсюда масштабное расширение и глубокое переосмысление всего тезауруса медиа. Авторы отразили это расширение по нескольким направлениям. Во введении точно подмечено, что появление новых слов, образованных от лексемы «медиа», оказалось «феноменально продуктивным»; их десятки, а в целом этот терминологический ряд может быть бесконечным. Основа расширения - это, разумеется, стремительное движение границ самого объекта. При небольших возможностях объема словаря удалось выявить и описать самый широкий круг понятий - от «глобализации» до «блогов» и «видеоигр», от «коммуникативистики» - до «газет» и «журналов», от «Интернета» - до «медиасобытия» и «формата».

Медиаполе, как показывают авторы, расширилось также за счет привлечения понятий, ранее не рассматривавшихся в контексте журналистики и публицистики. Среди них и знакомые в иных смысловых ракурсах «интеракция», «креативные индустрии», «лидер мнений», «массовая культура» (сегодня они трактуются как медийные понятия, что зафиксировано словарем), и менее известные и употребляемые, но существенно значимые «разрушительные технологии», "медиаактивизм».

В числе наиболее значимых результатов следует назвать обращение к хорошо известным понятиям, в течение многих лет вызывающих горячую полемику. Их смысл, при всей интуитивной ясности, «плывет» и вчера, и сегодня - сегодня более чем когда-либо раньше. Авторы смо- гли не только зафиксировать бесспорно общее значение многочисленных версий и толкований, но и показали, как меняется их наполнение в современной архитектуре медийных смыслов. Так, в словаре разделяются понятия «журнализм» и «журналистика», уточняются объемы стоящих за ними реалий, устраняется былая многопрофильность «журналистики». Вместе с этим знакомое всем слово обретает необходимую степень ясности и терминологичности. В трактовке производного от них понятия «журналист» актуализирована проблема идентичности, что помогает понятному прежде обозначению не исчезнуть в новых подтекстах и аллюзиях.

Авторы обращаются к ряду понятий, отражающих особо актуальные проблемы не только отечественного медиапространства, но и всего общества. Среди них, например, «медиаграмотность», «медиадискурс», «медиакратия», «медиапотребление». Введение их в активный словооборот посредством разъяснения смысла и содержания понятий, акцентирование проблемных аспектов привлекает внимание к их решению, способствует концентрации ресурсов. Понятие «доступ к информации», в частности, также отражает потенциально нуждающуюся в движении общественную и медийную проблему. И здесь важно подчеркнуть, что словарь не только определяет/толкует понятия, но и дает описание текущего состояния стоящих за ними противоречий. Тем самым авторы фиксируют сегодняшний статус понятий и стремятся избежать «догмы».

В некоторых случаях происходит закрепление сложившихся на практике понятий в том числе в ситуациях, когда слова с иноязычными корнями обрели русскоязычную форму и при этом несколько отошли от первоначального значения, обретя собственную судьбу в отечественном научном дискурсе. Такова, например, популярная ныне «гражданская журналистика», соеди- 
нившая два понятия, пришедших из практики американских медиа.

Отрадно отметить, что за привлечением большого числа новых понятий авторами не утрачена преемственность. В словаре немало терминов, хорошо знакомых старшему поколению исследователей и журналистов. Несмотря на солидный возраст, эти «старые» понятия не утратили своей актуальности. Более того, они также нуждаются в научной легитимности, в терминологизации, которая в свое время не была достигнута. Отсюда бытующие до сих пор старые и новые профессионализмы, традиционно различные в редакциях и подчас создающие психологический дискомфорт у выпускников вузов, получивших академическое образование. Многие из этих понятий обрели долгожданную ясность: "жанр», «творчество», «аудитория», «редакция». Преемственность, однако, не исключает инноваций. Так, в пассивное прежде понимание аудитории (читатели, слушатели, зрители) авторы, по существу, "вдохнули» новую жизнь, пояснив ее кардинально изменившуюся роль в медиапотреблении, производстве, необходимости развития медиаграмотности. Показан новый статус «информационных агентств». Не ушли авторы и от толкования «формата», долгое время остававшегося в ранге профессионализма, а не термина.

О наличии в глоссарии понятия «профессиональное творчество журналиста» следует сказать особо: современные функционеры медиа, медиаменеджеры нередко отказывают журналистике в творчестве, подменяя его требованием следовать исключительно технологиям. Но ведь следование технологиям не только не исключает творчества, но и освобождает для него время, силы, желание и другие ресурсы. Столь важное понятие, как профессиональ- ное творчество, в словаре присутствует, его трактовка не противоречит ни современным культурным концепциям, ни отечественным традициям журналистики - и это знаковый момент в концептуализации современных представлений о медиа и журналистике.

Отметим, что авторам словаря удалось в процессе работы успешно преодолеть целый ряд барьеров: множественность интерпретаций имеющихся определений,трудности отбора, необходимость инклюзии иноязычных понятий в закономерности отечественного словообразования, исходная «практикогенность» некоторых понятий и обретение ими научной легитимности. Именно легитимацию большинства медиапонятий, перешедших из статей и сборников, из дискурса конференций и научных дискуссий, из профессионального обихода в основы тезауруса современного журналиста, можно оценить как одно из главных достижений авторов.

К числу достоинств нового издания следует отнести также редакторскую и оформительскую культуру сборника: ясность и прозрачность стиля словарных статей, ссылки на источники и справочники, удобное визуальное оформление. Об источниках нужно сказать отдельно: они не перегружены, но несколько десятков упомянутых книг и статей, по существу, представляют собой musthave современного медиаисследователя. Словарь основателен и надежен как научно-теоретический источник, полезен как для преподавателей и студентов высших учебных заведений, так и практикующих журналистов. И, солидаризируясь с авторами в оценке его перспектив, надеемся, станет важным шагом на пути преодоления вариативности смыслов и улучшит качество научной коммуникации. 